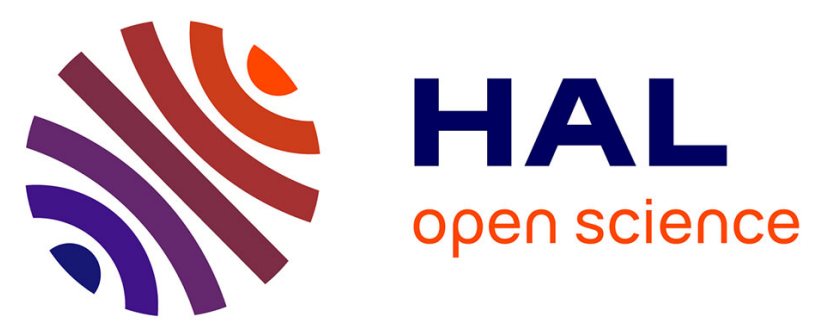

\title{
Lysozyme encapsulation into nanostructured CaCO3 microparticles using a supercritical CO2 process and comparison with the normal route
}

Leila N. Hassani, François Hindré, Thomas Beuvier, Brice Calvignac, Nolwenn Lautram, Alain Gibaud, Frank Boury

\section{To cite this version:}

Leila N. Hassani, François Hindré, Thomas Beuvier, Brice Calvignac, Nolwenn Lautram, et al.. Lysozyme encapsulation into nanostructured $\mathrm{CaCO} 3$ microparticles using a supercritical $\mathrm{CO} 2$ process and comparison with the normal route. Journal of materials chemistry B, 2013, 1 (32), Non spécifié. 10.1039/c3tb20467g . hal-03173121

\section{HAL Id: hal-03173121 \\ https://univ-angers.hal.science/hal-03173121}

Submitted on 18 Mar 2021

HAL is a multi-disciplinary open access archive for the deposit and dissemination of scientific research documents, whether they are published or not. The documents may come from teaching and research institutions in France or abroad, or from public or private research centers.
L'archive ouverte pluridisciplinaire HAL, est destinée au dépôt et à la diffusion de documents scientifiques de niveau recherche, publiés ou non, émanant des établissements d'enseignement et de recherche français ou étrangers, des laboratoires publics ou privés. 


\title{
Journal of \\ Materials Chemistry B
}

\section{Lysozyme encapsulation into nanostructured $\mathrm{CaCO}_{3}$ microparticles using a supercritical $\mathrm{CO}_{2}$ process and comparison with the normal route $\dagger$}

\author{
Leila N. Hassani, ${ }^{a}$ François Hindré, ${ }^{a}$ Thomas Beuvier, ${ }^{\mathrm{b}}$ Brice Calvignac, ${ }^{a}$ \\ Nolwenn Lautram, ${ }^{a}$ Alain Gibaud ${ }^{\mathrm{b}}$ and Frank Boury*a
}

\begin{abstract}
The aim of the present work was to assess the merits of supercritical $\mathrm{CO}_{2}\left(\mathrm{SC}-\mathrm{CO}_{2}\right)$ as a process for protein encapsulation into calcium carbonate microparticles. Lysozyme, chosen as a model protein, was entrapped during $\mathrm{CaCO}_{3}$ precipitation in two different media: water (normal route) and $\mathrm{SC}_{-} \mathrm{CO}_{2}$. The particles were characterized and compared in terms of size, zeta potential, morphology by SEM, crystal polymorph and lysozyme encapsulation. Fluorescent and confocal images suggested the encapsulation and core-shell distribution of lysozyme into $\mathrm{CaCO}_{3}$ obtained by the $\mathrm{SC}-\mathrm{CO}_{2}$ process. A high encapsulation efficiency was reached by a supercritical $\mathrm{CO}_{2}$ process $(50 \%)$ as confirmed by the increased zeta potential value, lysozyme quantification by HPLC and a specific bioassay (M. lysodeikticus). Conversely, lysozyme was scarcely entrapped by the normal route (2\%). Thus, supercritical $\mathrm{CO}_{2}$ appears to be an effective process for protein encapsulation within nanostructured $\mathrm{CaCO}_{3}$ particles. Moreover, this process may be used for encapsulation of a wide range of macromolecules and bioactive substances.
\end{abstract}

Received 2nd April 2013 Accepted 5th June 2013

DOI: $10.1039 / \mathrm{c} 3 \mathrm{tb} 20467 \mathrm{~g}$

www.rsc.org/MaterialsB controlled porosity, materials biocompatibility, encapsulation efficiency and protein stability. Recent progress of inorganic porous materials as protein delivery systems has shown their tremendous capacity in protein encapsulation and release, among which are porous silica $\mathrm{SiO}_{2},{ }^{3}$ calcium phosphate, ${ }^{4}$ hydroxyapatite $\mathrm{Ca}_{10}\left(\mathrm{PO}_{4}\right)_{6}(\mathrm{OH})_{2}$ (ref. 5) and calcium carbonate $\mathrm{CaCO}_{3}{ }^{6}$

Calcium carbonate is the most abundant mineral in nature and it exists in three anhydrous polymorphs: vaterite, aragonite and calcite (in the order of decreasing thermodynamic stability). Calcium carbonate is generally obtained chemically by simple mixing of calcium and carbonate salts. Different strategies have been proposed to control the crystallization. They are based on mimicking biomineralization in the presence of molecular templates or additives. Most of these studies have been centred on elucidating particle formation and understanding the kinetics and mechanisms of crystallization. ${ }^{7}$ Due to its high loading capacity, easy preparation and low price, $\mathrm{CaCO}_{3}$ is an effective material for protein encapsulation and drug delivery applications. This fact is supported by a number of scientific reports addressing loading of $\mathrm{CaCO}_{3}$ with functional nanoparticles, ${ }^{8}$ various bioactive molecules including low-molecular weight drugs, ${ }^{9-11}$ DNA, ${ }^{12,13}$ Si-RNA ${ }^{14}$ and a wide range of proteins. ${ }^{15,16} \mathrm{~A}$ number of protein loading modes into $\mathrm{CaCO}_{3}$ microspheres have been reported, including coprecipitation (active loading), ${ }^{6,15,17}$ physical adsorption (passive loading), ${ }^{9,17,18}$ interfacial reaction, ${ }^{12}$ phase transition ${ }^{19}$ and more recently chemical adsorption. ${ }^{20}$ The most effective technique was protein-co-precipitation, which leads to high protein 
encapsulation during the process of $\mathrm{CaCO}_{3}$ crystal growth. Unfortunately, protein inclusion efficiency was strongly dependent on the IEP (isoelectric point), in fact positively charged proteins (IEP > 7) are difficult to encapsulate and escape easily because of repulsion with calcium carbonate in aqueous media. ${ }^{15}$

We have previously demonstrated that a supercritical $\mathrm{CO}_{2}$ process can be used for the synthesis of hollow vaterite of $\mathrm{CaCO}_{3}{ }^{21,22}$ SAXS and USAXS experiments of these hollow spheres revealed a high specific area and hierarchical porosity including macropores and mesopores. ${ }^{23}$ Such porous properties are key properties attractive for drug and protein encapsulation as we reported in our last paper. ${ }^{24}$

Supercritical $\mathrm{CO}_{2}$-based processes are considered to be environmentally benign and their application as potential alternatives to conventional processes has been an active field of research during the past two decades. ${ }^{25} \mathrm{CO}_{2}$ is essentially nontoxic, non-inflammable and may be recycled. Its easily accessible critical conditions $\left(T=31.1{ }^{\circ} \mathrm{C}\right.$ and $P=73.8$ bar $)$ combined with its low cost lead to the supercritical $\mathrm{CO}_{2}$ process being an adequate and mild process to manipulate sensitive compounds such as therapeutic proteins. Supercritical $\mathrm{CO}_{2}$ is indeed one of the most studied supercritical fluids for a large panel of applications including dry protein preparation, protein precipitation, micronization, designing of nano- and microparticles, liposomal formulation, drug and protein encapsulation. ${ }^{25,26}$ To the best of our knowledge $\mathrm{SC}-\mathrm{CO}_{2}$ has been proposed for the preparation of $\mathrm{CaCO}_{3}$ particles by only a few research groups, ${ }^{27-30}$ and none of these studies reported drug or protein encapsulation.

In this paper, we present the preliminary investigations on the direct encapsulation of a model protein, lysozyme, into calcium carbonate microparticles using a $\mathrm{SC}-\mathrm{CO}_{2}$ process. We compared two different approaches for the direct encapsulation into $\mathrm{CaCO}_{3}$ microparticles. In the first approach, lysozyme was entrapped during the growth of $\mathrm{CaCO}_{3}$ particles in supercritical $\mathrm{CO}_{2}$, and in aqueous medium in the second one (called normal route). $\mathrm{CaCO}_{3}$ microparticles were thoroughly characterized in terms of morphology, size, surface charge and $\mathrm{CaCO}_{3}$ polymorphism. The stability of the encapsulated protein, protein loading and encapsulation efficiency were also assessed. The versatility of this novel process in overcoming the barriers encountered in the normal route was revealed by this comparative study.

\section{Experimental section}

\section{Materials}

The chemicals employed here are commercially available and listed as follows. Glycine (purity $\geq 99 \%$ ), dihydrated calcium chloride $\mathrm{CaCl}_{2} \cdot 2 \mathrm{H}_{2} \mathrm{O}(\geq 99.0 \%, \mathrm{C} 3881)$, calcium hydroxide $\mathrm{Ca}(\mathrm{OH})_{2}$ (purity 95\%, C7887), sodium carbonate $\mathrm{Na}_{2} \mathrm{CO}_{3}$ $\left(\geq 99.5 \%\right.$, S2127), hyaluronic acid (Streptococcus equi $53747, M_{\mathrm{w}}$ : 600-4000 kDa), lysozyme (14 kDa, IEP = 11.1, L-6876, from chicken egg white, protein $\geq 90 \%$ ), Micrococcus lysodeikticus (ATCC no 4698), fluorescein isothiocyanate FITC (F7250, $\geq 90 \%$ ), Tris-HCl buffer (tris-hydroxymethyl-aminomethane
$50 \mathrm{mM}$, sodium chloride $\mathrm{NaCl} 15 \mathrm{mM}, \mathrm{pH}=7.4$ ), sodium hydroxide $(\mathrm{NaOH})$, and sodium chloride $(\mathrm{NaCl})$ were purchased from Sigma-Aldrich Chemical (Saint Quentin Fallavier, France). A filter of $0.45 \mu \mathrm{m}$ (HVLP type, Millipore SA, Guyancourt-France) and a filter of $0.2 \mu \mathrm{m}$ for HPLC analysis (Acrodisc, PALL, USA) were purchased. Vectashield ${ }^{\circledR}$ hardset mounting medium (H-1400) was obtained from Vector laboratories. Medical carbon dioxide (purity 99.99\%) was obtained from Air Liquide, France. A dialysis membrane (Spectra/Por ${ }^{\circledR}$ MWCO $=6-8 \mathrm{kDa}$ ) was purchased from Spectrum ${ }^{\circledR}$ Labs-France. Purified water was obtained from a MilliQ Advantage A10 system (Millipore, Paris, France). Acetonitrile (HPLC quality) was obtained from Fischer Scientific, trifluoroacetic acid (TFA, HPLC quality $37 \%(w / w)$ was obtained from Carlo Erba, France). All samples were lyophilized in a freeze-dryer (Lyovax GT 2, Steris ${ }^{\circledR}$, France) for 18 hours.

\section{Lysozyme encapsulation using a $\mathrm{SC}-\mathrm{CO}_{2}$ process}

The calcium solution was prepared as described previously. ${ }^{22,24}$ Calcium hydroxide $\mathrm{Ca}(\mathrm{OH})_{2}(1 \% \mathrm{w} / \mathrm{v})$ was added to the glycine buffer $(0.62 \mathrm{M} \mathrm{NaCl}$ and $0.62 \mathrm{M}$ glycine), then the $\mathrm{pH}$ was adjusted to 10 and the solution was filtered through a $0.45 \mu \mathrm{m}$ filter (final concentration of $\mathrm{Ca}(\mathrm{OH})_{2}: 108 \mathrm{mM}$ ). Lastly, as an anionic organic template, hyaluronic acid (Fig. 1A) was added $(0.1 \% \mathrm{w} / \mathrm{v})$. Besides, glycine can act like an additive and aids in vaterite formation. ${ }^{31}$ To prepare loaded microspheres, lysozyme was dissolved in the aqueous calcium solution at a starting concentration of 0.5 and $1.0 \mathrm{~g} \mathrm{~L}^{-1}$. A schematic diagram of the used device for $\mathrm{CaCO}_{3}$ microsphere synthesis is shown in Fig. 1B. A stainless steel autoclave (1) with a capacity of $500 \mathrm{~mL}$ (Separex, Champigneulles, France) was heated at $40.0 \pm 0.1{ }^{\circ} \mathrm{C}$, and pressurised with $\mathrm{CO}_{2}$ at $200 \pm 1$ bar. Liquid $\mathrm{CO}_{2}$ was pumped using a high pressure membrane pump at $1 \mathrm{~kg} \mathrm{~h}^{-1}$ (Milton Roy Europe, Pont Saint Pierre-France) (2) and preheated using a heat exchanger (3) before feeding the autoclave. The

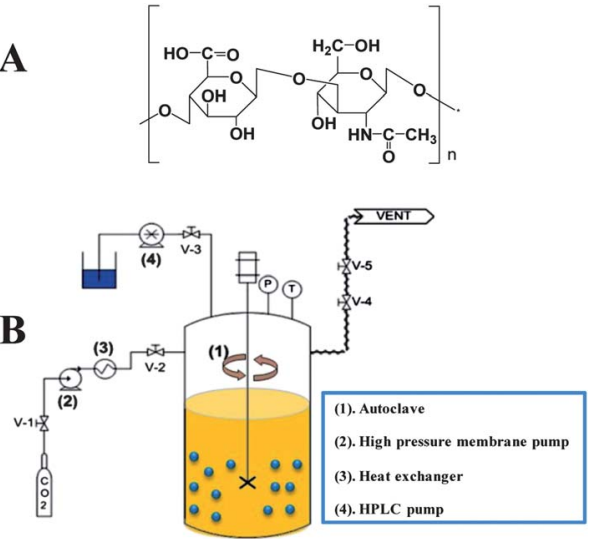

Fig. 1 (a) A chemical structure of the organic template (hyaluronic acid). (b) Experimental set-up for the supercritical $\mathrm{CO}_{2}$ process. $\mathrm{CO}_{2}$ is first brought to supercritical conditions within the autoclave (200 bar and $40{ }^{\circ} \mathrm{C}$ ). A water-insupercritical $\mathrm{CO}_{2}$ emulsion is prepared by addition of a solution made of glycine buffer, $\mathrm{Ca}(\mathrm{OH})_{2}$, hyaluronic acid and the protein of interest to be encapsulated. After injection of the aqueous phase, stirring at $1400 \mathrm{rpm}$ is maintained for $5 \mathrm{~min}$, prior to slow depressurization (40-50 bar $\mathrm{min}^{-1}$ ). After washing with ultrapure water, the obtained $\mathrm{CaCO}_{3}$ microparticles are finally lyophilized before storage. 
stirring speed was set at $1200 \mathrm{rpm}$, with a Teflon coated stirrer (Top-industrie, Vaux le Penil, France). Once, the equilibrium was reached (i.e. stable temperature and pressure), the previously prepared calcium aqueous solution $(25 \mathrm{~mL})$ was injected using an HPLC pump (4) (Model 307, Gilson, Villiers le Bel,

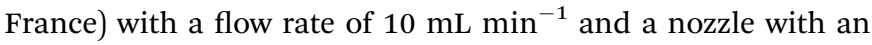
inner diameter of $1 \mathrm{~mm}$. Once injection is achieved, the final pressure was $240 \pm 5$ bar and the stirring was maintained at $1200 \mathrm{rpm}$ for $5 \mathrm{~min}$. Thereafter, the stirring was stopped and the autoclave was depressurised at a rate of 40-50 bar $\min ^{-1}$ prior to lyophilisation of the $\mathrm{CaCO}_{3}$ microspheres.

\section{Lysozyme encapsulation using the normal route}

Precipitation of $\mathrm{CaCO}_{3}$ was carried out by mixing an equal volume of calcium containing solution $\left(\mathrm{Ca}(\mathrm{OH})_{2} 217 \mathrm{mM}\right)$ and carbonate containing solution $\left(\mathrm{Na}_{2} \mathrm{CO}_{3}, 217 \mathrm{mM}\right)$. The two solutions were prepared in glycine buffer as described previously. To obtain lysozyme loaded $\mathrm{CaCO}_{3}$ particles, an appropriate amount of lysozyme (for a final concentration of 0.5 and $1.0 \mathrm{~g} \mathrm{~L}^{-1}$ ) was added to the calcium containing solution. After stirring for $5 \mathrm{~min}$, the obtained suspension was centrifuged for 10 minutes at $4000 \mathrm{rpm}$ and room temperature and washed twice when particles were unloaded. Finally $\mathrm{CaCO}_{3}$ microparticles were freeze-dried.

\section{FITC-labeled lysozyme synthesis}

The labeling reaction was performed with fluorescein isothiocyanate (FITC), according to the reported procedure. ${ }^{32}$ Briefly: FITC (33 mg) dissolved in DMSO (1.65 mL) was slowly added to a solution of lysozyme $(250 \mathrm{mg})$ in $\mathrm{Na}_{2} \mathrm{CO}_{3}(25 \mathrm{~mL}$, $0.1 \mathrm{M}, \mathrm{pH}$ 8). After $2 \mathrm{~h}$ of stirring in the dark at room temperature, the solution was dialyzed extensively in the dark overnight against purified water $(\mathrm{pH}$ 7.1) until it became colorless. The FITC-labeled lysozyme was freeze-dried and only incorporated into the calcium solution (at a starting concentration of 0.5 and $1.0 \mathrm{~g} \mathrm{~L}^{-1}$ ) when preparing microparticles (in supercritical $\mathrm{CO}_{2}$ and in aqueous media). $\mathrm{CaCO}_{3}$ microparticles were washed once with $50 \mathrm{~mL}$ of purified water and freeze-dried before fluorescence and confocal microscopy analysis.

\section{$\mathrm{CaCO}_{3}$ microparticle characterization}

Scanning electron microscopy. To study the morphology, the microstructure and calculate the diameter of $\mathrm{CaCO}_{3}$ microparticles (see ESI $\dagger$ ), lyophilized samples were sputtered with gold using a high vacuum metal evaporation coater MED 020 (BalTec, Balzers, Lichtenstein) and observed using a scanning electron microscope (SEM. Jeol 6301F) at an operating voltage of $3 \mathrm{keV}$.

Optical microscopy. The microparticles were dispersed in a droplet of water, directly on a slide and immediately observed under an optical microscope (Olympus, Japan) equipped with a CCD camera QIClick and a computerized image analyzer Q capture Pro 6.2 (QImaging, Briscous, France).

Light scattering instrument. Mean size and size distribution measurements of microparticles were performed using a particle size analyzer PSA in liquid medium (Malvern
Mastersizer with hydro 2000S wet dispersion accessory, France). The laser diffusion intensity is recorded as a function of the angle of diffusion, and then application of the Fraunhofer diffraction and Mie scattering theories allows the size of the particles and their repartition in number and volume to be obtained. The mean number-based diameter $D_{N}$ was calculated from the number distribution according to eqn (1). Distribution widths were determined by the SPAN factor as expressed in eqn (2). $D_{10}, D_{50} D_{90}$ percentiles are the diameters at $10 \%, 50 \%$ and $90 \%$ cumulative volume, respectively. A high value of SPAN indicates a wide distribution in size and polydispersity. Results are an average of five measurements; a refractive index of 1.61 and absorption of 0.01 were used with a stirring rate of 1500 rpm with no ultrasound.

$$
\begin{gathered}
D_{N}=\frac{\sum(\text { frequency in number } \% \times \text { sizes })}{\sum \text { frequency in number } \%} \\
\text { SPAN }=\frac{D_{90}-D_{10}}{D_{50}}
\end{gathered}
$$

Zeta potential. A Nanosizer ZS® (Malvern Instruments, Orsay, France) operating at $150 \mathrm{~V}$ and at room temperature was used to assess microspheres' electrical surface charge calculated by the Smoluchowski theory. Microspheres were dispersed in ultrapure water (Millipore, $10 \mathrm{~mL}$ ) and mixed prior to every measurement. The zeta cell was washed with ultrapure water between every measurement.

Optical fluorescence imaging. Samples were viewed using the same microscope as below equipped with epifluorescent attachment and a mercury arc lamp light source (Olympus Provis, Japan). Fluorescence images were captured and treated with the same software.

Confocal laser scanning microscopy (CLSM). Fluorescence microscopy was used to evaluate the distribution of FITClysozyme in $\mathrm{CaCO}_{3}$ microspheres. An Olympus FV300 Laser Scanning Confocal Imaging System (Olympus, Japan), equipped with an argon ion laser (Melles Griot, Voisins Le Bretonneaux, France) and an Olympus BX50 microscope (Olympus, Japan), was used to investigate the structure and morphology of the microparticles. All confocal fluorescence pictures were taken with a $60 \times$ objective: oil immersion, numeric aperture 1.40 (numerical zoom of 2). The used software for the CLSM imaging was Fluoview ${ }^{\circledR V}$ Version 3.3. (Olympus, Japan). The laser was adjusted in the green fluorescence mode, which yielded two excitation wavelengths at 488 and $543 \mathrm{~nm}$. The images were obtained for dry microparticles mounted on a slide with $10 \mu \mathrm{L}$ of Vectashield ${ }^{\circledR}$ and coverslipped.

$\mathrm{X}$-ray diffraction. The crystal structures of the $\mathrm{CaCO}_{3}$ microspheres synthesised in supercritical $\mathrm{CO}_{2}$ or in aqueous medium were characterized by X-ray diffraction. XRD analysis was carried out using an X-pert diffractometer (CuK $\alpha 1 \alpha 2$ doublet, $\lambda=1.54056 \AA$, from $2 \theta=10$ to $70^{\circ}$ in continuous mode with a step size of $0.07^{\circ}$ ).

Protein quantification. Two different assays were used in order to determine the lysozyme loading (LL\%, eqn (2)) and the 
encapsulation efficiency (EE\%, eqn (3)). Quantification was always performed in triplicate for each microsphere batch. Before each measurement, unloaded and lysozyme-loaded microspheres $(5 \mathrm{mg}$ ) were dissolved by contact with $\mathrm{HCl}$ $(1.5 \mathrm{~mL}, 0.1 \mathrm{M})$ for $10 \mathrm{~min}$.

$$
\begin{gathered}
\mathrm{LL} \%=\frac{\text { quantified amount of lysozyme }}{\mathrm{mg} \text { of microparticles }} \times 100 \\
\mathrm{EE} \%=\frac{\text { quantified lysozyme in microparticles }}{\text { initial amount of lysozyme in calcium solution }} \times 100
\end{gathered}
$$

1 Total protein quantification by HPLC (high performance liquid chromatography). This method is based on specific interaction of the lysozyme with the stationary phase and not related to the activity of the lysozyme. Thus it allows the quantification of lysozyme independently of the protein activity. HPLC assay was conducted using a PLRPS-column (polymeric reversed phase column; PLRP-S $2504.6 \mathrm{~mm}, 300 \AA$ pore size, $5 \mu \mathrm{m}$ particle size; Agilent, Massy, France) and followed by detection with a photodiode array detector (PDA 996, Waters, Guyancourt-France) set at $280 \mathrm{~nm}$ (ref. 33) An absorbance spectrum was taken between 210 and $400 \mathrm{~nm}$ in order to confirm the identity of the peak and as such guarantee the specificity of the analysis. The system was equipped with a mobile phase delivery pump (600, Waters, Guyancourt, France), an auto sampler (717 Plus, Waters, Guyancourt, France), an on-line degasser (AF, Waters, Guyancourt, France) and a column oven (CHM, Waters, Guyancourt, France) set at $45{ }^{\circ} \mathrm{C}$.

Typically, the filtered sample $(50 \mu \mathrm{L})$ was injected into the column. The flow rate was $1 \mathrm{~mL} \mathrm{~min}^{-1}$, and the mobile phase consisted of a gradient of water and acetonitrile both containing $0.1 \%$ trifluoroacetic acid (v/v). Eluting conditions expressed as proportion of water with $0.1 \%$ TFA were as follows: $0-10 \mathrm{~min}$ : 69\%, 19 min: 49.3\%, 20 min: 25\%, 20-21 min: 25\%, 22 min: $69 \%, 22-30 \mathrm{~min}: 69 \%$. The lysozyme peak was identified in the chromatograms at a retention time of $20 \mathrm{~min}$. Calibration curves were drawn up from 1.5 to $800 \mu \mathrm{g} \mathrm{mL} \mathrm{m}^{-1}$ in the mobile phase.

2 Bioassay for active lysozyme quantification. This assay is based on the hydrolysis of $\beta-1,4$ glycosidic linkages between $N$-acetylglucosamine and $N$-acetylmuramic acid in bacterial cell walls of Micrococcus lysodeikticus, caused by the lysozyme, which results in a decreased bacterial suspension turbidity. ${ }^{34}$ The bacterial suspension $(0.015 \% \mathrm{w} / \mathrm{v})$ was prepared by adding $30 \mathrm{mg}$ of $M$. Lysodeikticus in $200 \mathrm{~mL}$ Tris-HCl buffer (pH 7.4) and incubated at $37{ }^{\circ} \mathrm{C}$ for one hour. Then lysozyme-loaded microspheres $(5 \mathrm{mg}$ ) were dissolved by contact with $\mathrm{HCl}$ $(1.5 \mathrm{~mL}, 0.1 \mathrm{M})$ for $10 \mathrm{~min}$ and diluted in Tris-HCl buffer to reach a concentration of 0.1 to $1 \mu \mathrm{g} \mathrm{mL} \mathrm{m}^{-1}$ of lysozyme. Lysozyme solution $(100 \mu \mathrm{L})$ of samples or standards $\left(0.1\right.$ to $\left.1 \mu \mathrm{g} \mathrm{mL}{ }^{-1}\right)$ was added to M. Lysodeikticus suspension $(2.9 \mathrm{~mL})$ in polypropylene tubes (Gosselin, Fisher Scientific) and incubated for 4 hours at $37{ }^{\circ} \mathrm{C}$. The turbidity was finally assessed by measuring the absorbance at $450 \mathrm{~nm}$ (UV2600 UV-Vis spectrophotometer equipped with a UV Probe 2.42 software, Shimadzu, Marne la Vallée, France).

Statistical analysis. All the data were expressed as mean \pm standard deviation (SD). Differences were analyzed statistically by Student's $t$-test. The acceptable level of statistical significance was set at a probability of less than 0.05 .

\section{Results and discussion}

\section{Comparison of morphology, size and zeta potential}

Morphologies of $\mathrm{CaCO}_{3}$ particles prepared by both the supercritical process and the normal route are depicted in optical micrographs (Fig. 1, ESI $\dagger$ ) and SEM images in (Fig. 2). Unloaded $\mathrm{CaCO}_{3}$ microspheres formulated by the supercritical process (Fig. 2A) had spherical shapes with relatively rough surfaces as observed in our previous work..$^{22}$ The microspheres are constituted of an assembly of vaterite nanograins (about $40 \mathrm{~nm}$ in width) and exhibit a specific surface of $16 \mathrm{~m}^{2} \mathrm{~g}^{-1}$ with a mesoporosity of around $11 \%$ as recently reported. ${ }^{23}$ When lysozyme was encapsulated (at 0.5 and $1 \mathrm{~g} \mathrm{~L}^{-1}$ initial concentration), similar $\mathrm{CaCO}_{3}$ particles with spherical shapes were obtained (Fig. 2A). The same morphology with a smaller size was observed for the microparticles obtained by the normal route as already reported by other research groups. ${ }^{6,15,16,35,36}$

Mean size and size distribution of $\mathrm{CaCO}_{3}$ microspheres were measured using PSA as shown in Fig. 2 (ESI $\dagger$ ). Granulometric curves averaged over 5 measurements runs ( 3 batches) indicate a non-symmetric and strongly unimodal particle size distribution for all microparticles, with variability of size distribution, number percentage and modal peak size. It is noteworthy that almost no microparticles displayed a diameter higher than 10 $\mu \mathrm{m}$. Cross-checking the results from size distribution is achieved by comparing the behavior of mean diameter and statistical parameters including the mode and percentiles, among which $D_{10} D_{50} D_{90}$ and the SPAN are listed in Table 1 (ESI $\dagger$ ).

For $\mathrm{CaCO}_{3}$ microspheres obtained by a supercritical process there was no significant influence of the lysozyme and lysozyme concentration on particle mean diameter (ESI $\dagger$, Table 1). However, statistical analysis of mode, median and percentiles indicates a slight decrease in particle diameter when encapsulating lysozyme, resulting in different particle size distributions (ESI†, Fig. 2). The presence of proteins affects the crystallization process thus leading to a decrease in the microparticle size as demonstrated by Petrov et al. ${ }^{6}$ Lysozyme adsorbs on the surface of primary nanocrystallites and increases the nucleation rate, thus resulting in a decrease of the mean diameter of $\mathrm{CaCO}_{3}$ particles. $^{37}$

In the same study it was also reported that changing agitation time may increase the particle size, thus underlining that there are several parameters involved in the size control of $\mathrm{CaCO}_{3}$ in the supercritical $\mathrm{CO}_{2}$ process. Particles obtained by the normal route were about $3 \mu \mathrm{m}$ in diameter but adding lysozyme slightly increases the particle mean diameter as well as percentiles (ESI†, Table 1), although $\mathrm{CaCO}_{3}$ microparticles exhibited the same mode, median and thus the same size distribution (ESI†, Fig. 2). According to the literature, $\mathrm{CaCO}_{3}$ exhibits negative or positive charges depending on its 


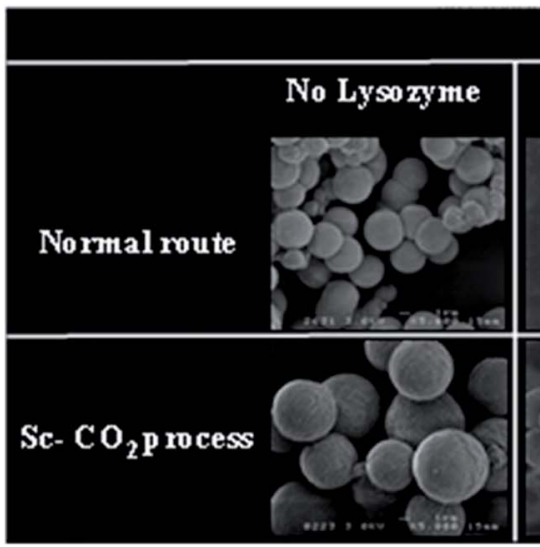

\section{A}
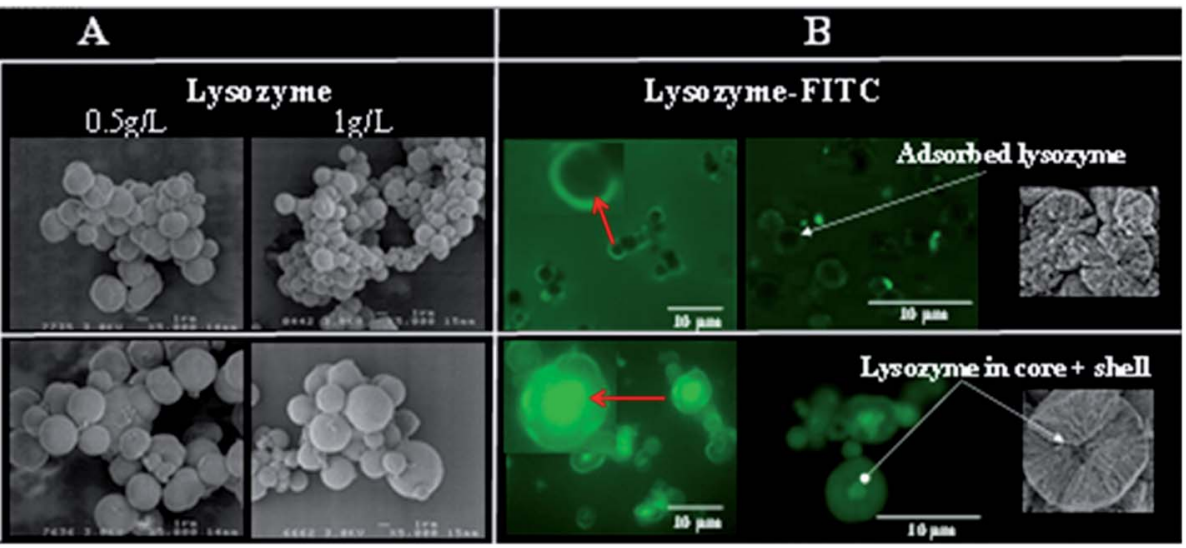

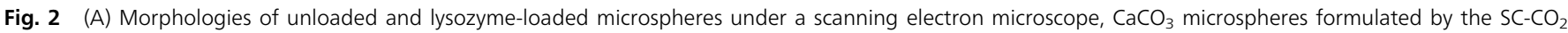

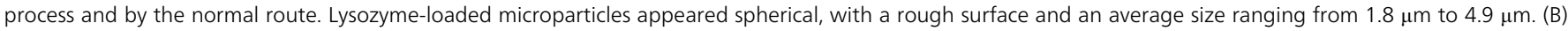

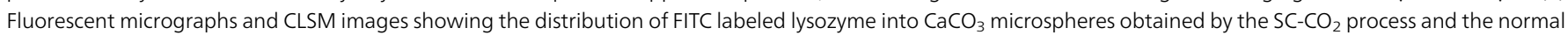
route, the inset represents SEM images of broken microparticles obtained from ref. 23.

polymorph morphology and composition. Vaterite polymorph mostly bears positive charges and calcite bears negative charges. ${ }^{38}$ Unloaded $\mathrm{CaCO}_{3}$ microparticles (IEP $=8.5$ (ref. 39)) obtained by both the supercritical $\mathrm{CO}_{2}$ process and the normal route are essentially made of vaterite and exhibit a negative zeta potential in ultra-purified water (Table 1). This could be explained by the presence of the polyanionic glycosaminoglycan: hyaluronic acid $\left(\mathrm{p} K_{\mathrm{a}}=3.0\right){ }^{40}$ The $\xi$-potential of $\mathrm{CaCO}_{3}$ obtained by the supercritical process was $-20.8 \pm 2.5 \mathrm{mV}$ and increases to $-12.1 \pm 0.7$ and $-6.7 \pm 2.2 \mathrm{mV}$ at $0.5 \mathrm{~g} \mathrm{~L}^{-1}$ and $1.0 \mathrm{~g} \mathrm{~L}^{-1}$ lysozyme starting concentration respectively. This can result from the encapsulation of the positively charged lysozyme $(\mathrm{IEP}=11.1)$ into $\mathrm{CaCO}_{3}$. By contrast, the $\xi$-potential of $\mathrm{CaCO}_{3}$ obtained by the normal route was constant $(-14 \mathrm{mV})$ whatever the initial concentration of lysozyme. It is also expected that no lysozyme was encapsulated in $\mathrm{CaCO}_{3}$ using the normal route. These assumptions were confirmed by CLSM images, and lysozyme quantification.

Fluorescence micrographs and CLSM observations in Fig. 2B proved the successful lysozyme-FITC encapsulation into $\mathrm{CaCO}_{3}$ using the supercritical $\mathrm{CO}_{2}$ process. Whereas no labeled lysozyme was entrapped by the normal route, specific core shellstructure with high fluorescent intensity in the microparticle cores and homogeneous fluorescent distribution on the shell was obtained in the supercritical $\mathrm{CO}_{2}$ process (Fig. 2B). This suggests that lysozyme-FITC was incorporated both in the inner part of the particles and also within the porous shell. As previously observed under a scanning electron microscope, ${ }^{22}$ the $\mathrm{CaCO}_{3}$ microspheres were constituted of macro- and mesoporous shells with hollow cores. While for most of microparticles obtained by the normal route, no fluorescence was observed inside the particles but outside a fluorescent shell surrounding the microparticles. Consequently we suppose that lysozyme-FITC could be adsorbed at the particle surface, by means of electrostatic interactions.

Several studies aimed at controlling the morphology of $\mathrm{CaCO}_{3}$ (towards calcite, aragonite or vaterite), either by increasing the $\mathrm{CO}_{2}$ pressure, by ultrasonic irradiation or by addition of macromolecules in the aqueous phase. ${ }^{41,42}$ In this sense, to favour formation of vaterite during formation of porous $\mathrm{CaCO}_{3}$ microparticles, some studies described the use of acid homopolymers, block copolymers and dendrimers. ${ }^{7}$ In this study, all $\mathrm{CaCO}_{3}$ particles obtained by either the supercritical process or the normal route consisted of almost pure vaterite as revealed by XRD analysis (ESI $\dagger$ ). These results suggest that the presence of lysozyme, lysozyme concentration and the used process did not cause any changes in $\mathrm{CaCO}_{3}$ polymorph. In our case, vaterite morphology may be driven by the presence of glycine. ${ }^{31,43,44}$

Table 1 Overview of microspheres characteristics, lysozyme loading and encapsulation efficiency

\begin{tabular}{llllll}
\hline Samples & $\begin{array}{l}\text { Lysozyme } \\
\text { concentration }\left(\mathrm{g} \mathrm{L}^{-1}\right)\end{array}$ & $\begin{array}{l}\text { Zeta } \\
\text { potential } \xi(\mathrm{mV})\end{array}$ & $\begin{array}{l}\text { Total } \\
\text { lysozyme loading }\end{array}$ (\%) & $\begin{array}{l}\text { Active } \\
\text { lysozyme loading }^{c}(\%)\end{array}$ & Encapsulation yield $(\%)$ \\
\hline \multirow{2}{*}{$\begin{array}{l}\text { Supercritical } \mathrm{CO}_{2} \\
\text { process }\end{array}$} & $0^{a}$ & $-20.8 \pm 2.5$ & - & - & - \\
& 0.5 & $-12.1 \pm 0.7$ & $1.5 \pm 0.3$ & $1.40 \pm 0.5$ & $22.1 \pm 2.2$ \\
Normal route & 1.0 & $-6.7 \pm 2.2$ & $5.8 \pm 1.0$ & $5.8 \pm 1.1$ & $50.5 \pm 9.3$ \\
& $0^{a}$ & $-14.1 \pm 1.2$ & - & - & - \\
& 0.5 & $-14.8 \pm 1.3$ & $<0.1$ & $<0.1$ & $1.2 \pm 0.1$ \\
& 1.0 & $-14.5 \pm 2.3$ & $<0.2$ & $<0.2$ & $2.3 \pm 0.4$
\end{tabular}

${ }^{a}$ Experiment without lysozyme, results are represented as means \pm s.d. of 3 measurements. ${ }^{b}$ As determined by HPLC. ${ }^{c}$ By M. lysodeikticus bioassay. 
We observed that if we inject the solution of calcium without glycine during the supercritical $\mathrm{CO}_{2}$ process, $\mathrm{CaCO}_{3}$ precipitates in the phase of calcite as revealed by XRD (data not shown). Thus the presence of glycine is important in order to stabilize the vaterite phase. Moreover, hyaluronic acid acts as an organic template and control the crystal growth of thermodynamically unstable $\mathrm{CaCO}_{3}$ vaterite. ${ }^{45}$

Proteins are also known to play an important role in the crystallization of calcium carbonate. ${ }^{46} \mathrm{CaCO}_{3}$ can crystallize in the presence of bovine serum albumin (BSA), ${ }^{47}$ fibrin, ${ }^{48}$ lysozyme $^{38}$ casein $^{49}$ and gelatin. ${ }^{50}$ Besides $\mathrm{CaCO}_{3}$ crystallisation is not only dependent on the presence, concentration and nature of additives and/or molecular templates, but it is also highly dependent on the experimental parameters such as temperature ${ }^{51}$ stirring, reaction time, ${ }^{19,52}$ pressure and $\mathrm{pH}^{53}$

There is another important parameter depending on the polymorph which is $K_{\mathrm{sp}}$. Its magnitude is the product of the $\mathrm{Ca}^{2+}$ and $\mathrm{CO}_{3}{ }^{2-}$ ion concentrations that are just high enough to achieve a saturated solution in which the ions are in equilibrium with solid $\mathrm{CaCO}_{3}$. At $25^{\circ} \mathrm{C}$ and 1 bar, $K_{\text {sp(calcite) }}=10^{-8.47}$ and $K_{\mathrm{sp} \text { (aragonite) }}=10^{-8.22}$. For vaterite, the least stable of the three polymorphs, $K_{\mathrm{sp}}$ is smaller $\left(10^{-7.9}\right)$. Although referred to as a constant, $K_{\mathrm{sp}}$ varies with temperature, salinity and also with pressure. It has been observed that $K_{\text {sp }}$ of aragonite is about 2.7 times larger at 1000 bar. ${ }^{54}$ As a consequence, this suggests that deep ocean may be undersaturated with calcium carbonate. For calcite, the same evolution of $K_{\mathrm{sp}}$ has been observed. According to our knowledge, no study of $K_{\mathrm{sp}}$ as a function of pressure was reported for vaterite. If we suppose that $K_{\mathrm{sp}}$ increases with pressure like for calcite and aragonite, the precipitation of the $\mathrm{CaCO}_{3}$ vaterite particles may be less important under pressure.

The crystallization mechanism occurring in the supercritical $\mathrm{CO}_{2}$ process is still under investigation by our research groups. Time-resolved small-angle and wide-angle X-ray scattering experiments (SAXS/WAXS) were conducted for the first time on the mixture of $\mathrm{Ca}^{2+}$ aqueous solution and $\mathrm{SC}-\mathrm{CO}_{2}$ in a continuous flow, completed by in situ $\mathrm{pH}$ monitoring, Raman spectroscopy and turbidity measurements using a high-pressure cell (work is still in progress).

\section{Comparison of lysozyme loading and encapsulation yield}

The LL and EE are summarized in Table 1. Two different methods were used to quantify the amount of protein encapsulated within $\mathrm{CaCO}_{3}$ microspheres. The HPLC method was used to quantify the total amount of encapsulated lysozyme, while M. Lysodeikticus assay was used to quantify the amount of bioactive encapsulated lysozyme. We observed the successful and highly efficient encapsulation of lysozyme (LL almost 6\% and $\mathrm{EE}=50 \%$ for $1.0 \mathrm{~g} \mathrm{~L}^{-1}$ starting concentration) during the SC- $\mathrm{CO}_{2}$ process as confirmed by both HPLC and M. Lysodeikticus quantification methods. Total and active EE are nearly the same, thus lysozyme retains almost $100 \%$ of its activity after encapsulation by the $\mathrm{SC}-\mathrm{CO}_{2}$ process. Decreasing the initial lysozyme concentration to $0.5 \mathrm{~g} \mathrm{~L}^{-1}$ leads to a decrease of $\mathrm{LL}$ and EE. It is noteworthy that loading efficiency is a crucial parameter that we could easily tune by varying the starting lysozyme concentration. Concerning the normal route, as shown in Table 1 the lysozyme was scarcely encapsulated. The LL is $<1 \%$ and the EE is around 1 and $2 \%$ for the two starting concentrations ( $0.5 \mathrm{~g} \mathrm{~L}^{-1}$ and $1.0 \mathrm{~g} \mathrm{~L}^{-1}$ respectively).

We can compare lysozyme loading of microparticles obtained by the $\mathrm{SC}-\mathrm{CO}_{2}$ process and the normal route at the same starting lysozyme concentration: 1.0 and $0.5 \mathrm{~g} \mathrm{~L}^{-1}$. The first process allowed a higher encapsulation efficiency and a high conservation of lysozyme activity. To explain such differences, we infer that the key parameter for lysozyme encapsulation could be the $\mathrm{pH}$. During the normal route, the $\mathrm{pH}$ remained stable $(=10)$, which is close to the lysozyme's IEP (11.1). The lysozyme is also slightly positively charged and as a consequence the electrostatic interaction is weak with carbonate ions. Conversely, in the $\mathrm{SC}-\mathrm{CO}_{2}$ process, the dissolution of acid $\mathrm{CO}_{2}$ molecules in the aqueous solution induces a significant decrease of the $\mathrm{pH}$. After the depressurisation, the $\mathrm{pH}$ is around 6.5 which shows that under pressure, the $\mathrm{pH}$ is below this value. The interaction of lysozyme is then higher with $\mathrm{CO}_{3}{ }^{2-}$ which favors lysozyme entrapment inside $\mathrm{CaCO}_{3}$ particles.

During $\mathrm{CaCO}_{3}$ precipitation, it is well known that the $\mathrm{pH}$ influences the formation of $\mathrm{CaCO}_{3}$ due to its impact on carbonate concentration $\mathrm{CO}_{3}{ }^{2-}$ and thus the supersaturation. Besides the $\mathrm{pH}$ influences the charges of both lysozyme and $\mathrm{CaCO}_{3}$, as a consequence it affects electrostatic interactions that govern lysozyme entrapment. However, we also observed that lysozyme is not encapsulated by the normal route even when the precipitation is done at $\mathrm{pH}=6.5$. This highlights that the encapsulation within $\mathrm{CaCO}_{3}$ microspheres is not only governed by the $\mathrm{pH}$. The versatility of $\mathrm{SC}-\mathrm{CO}_{2}$ requires the understanding of lysozyme encapsulation by in situ analyses, which are still under investigation by our research group.

Active loading in aqueous media has been used for protein encapsulation. ${ }^{15}$ High encapsulation efficiencies were reported for negatively charged proteins, $\alpha$-lactalbumin (96\%), HSA (93\%) and IgG (94\%), with both low and high molecular weight. Though, $<1 \%$ of positively charged lysozyme was entrapped in $\mathrm{CaCO}_{3}$ cores. The reason for this, as explained by the authors, was that both $\mathrm{CaCO}_{3}$ and lysozyme were positively charged, so electrostatic repulsions inhibited the adsorption of lysozyme on the $\mathrm{CaCO}_{3}$ surface and thus the loading. Interestingly, a study described the encapsulation of small molecules, as well as proteins, within $\mathrm{CaCO}_{3}$ nanoparticles using this conventional method, but neither loading nor encapsulation efficiency data were available in the case of the studied proteins. ${ }^{55}$ In this study it was shown that active loading of erythropoietin $\left(M_{\mathrm{w}}=34 \mathrm{kDa}\right.$, $\left.\mathrm{p} K_{\mathrm{a}}=3.3-4.3\right)$ into $\mathrm{CaCO}_{3}$ nanoparticles was more effective than passive loading. In contrast, passive loading processes onto $\mathrm{CaCO}_{3}$ particles based on the impregnation of preformed $\mathrm{CaCO}_{3}$ microspheres may only be efficient with small compounds that are able to diffuse within the pores. Furthermore, molecular interactions between the $\mathrm{CaCO}_{3}$ surface and the protein is an important parameter. The adsorption is not only affected by the global electrostatic forces ${ }^{39}$ but is also dominated by steric interactions, such as changes in the hydration state and rearrangement of the macromolecular 
(1)

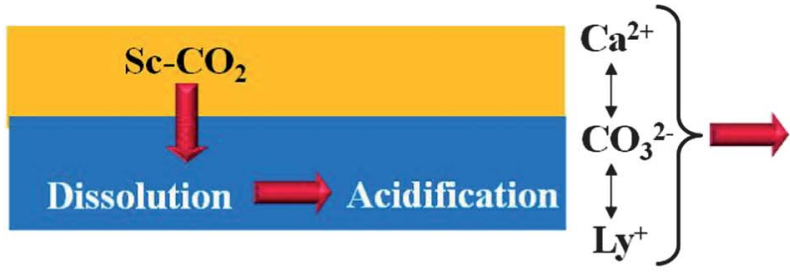

(2)

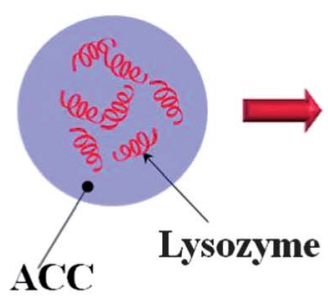

(3)

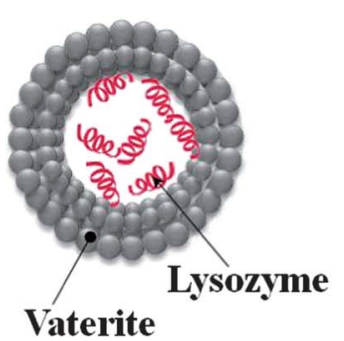

\section{Sc- $\mathrm{CO}_{2}$ dissolution and acidification of $\mathrm{Ca}^{2+}$ aqueous solution}

\section{Dissolution of $\mathrm{ACC}$ and vaterite precipitation}

Fig. 3 Proposed mechanism for microparticle formation and lysozyme encapsulation, ACC for amorphous calcium carbonate.

structure. Petrov et $a .^{6}{ }^{6}$ compared two different ways to prepare protein loaded $\mathrm{CaCO}_{3}$ microparticles, physical adsorption and co-precipitation. In this study it was found that co-precipitation$\alpha$-chymotrypsin capture by $\mathrm{CaCO}_{3}$ microparticles was five times more effective than the adsorption. In addition the encapsulated $\alpha$-chymotrypsin recovered $85 \%$ of the enzymatic activity.

An interesting study describes that the use of the interfacial reaction based on water-in-oil-in-water $(\mathrm{W} / \mathrm{O} / \mathrm{W})$ emulsion leads to a successful encapsulation of ovalbumin ( $43 \mathrm{kDa})$ and bovine serum albumin (BSA, $66 \mathrm{kDa}$ ) into $\mathrm{CaCO}_{3}$ microcapsules, ${ }^{12}$ encapsulation efficiency was $36 \%$, and $92 \%$ respectively. It is noteworthy that these authors demonstrated that the molecular weight of the protein to be encapsulated was proportional to the encapsulation yield. However, using this strategy, papain $(20 \mathrm{kDa})$ was scarcely encapsulated $(5.2 \%)$ and no inclusion of lysozyme was found. A few years later, ${ }^{19}$ they demonstrated that proteins could be encapsulated during the phase transition of the microspheres from vaterite to calcite, independent of their molecular weight. They succeeded in small protein encapsulation (lysozyme and insulin) with only $0.2 \%$ of lysozyme loading corresponding to an encapsulation efficiency of $17 \%$.

Using the $\mathrm{SC}-\mathrm{CO}_{2}$ process, we successfully obtained a high encapsulation efficiency of lysozyme. This in addition permitted to retain lysozyme biological activity. Here we compared two solvent free processes for direct encapsulation of lysozyme into $\mathrm{CaCO}_{3}$ microparticles, we proved that $\mathrm{SC}-\mathrm{CO}_{2}$ plays an important role in encapsulating a higher amount of lysozyme. The efficiency is expected to be enhanced if we enhance $\mathrm{CaCO}_{3}$ particle formation by increasing the concentration of $\mathrm{Ca}^{2+}$, because more particles are formed when more proteins are captured by $\mathrm{CaCO}_{3}$ microparticles. ${ }^{\mathbf{1 6}}$

SC- $\mathrm{CO}_{2}$ has been largely used for protein precipitation and processes, ${ }^{56}$ it was demonstrated that a supercritical $\mathrm{CO}_{2}$ process offers optimal conditions in terms of protein stability and integrity. ${ }^{57}$ Furthermore we need more investigation to understand the dynamics of lysozyme adsorption on calcium carbonate during its crystallization in supercritical media, and protein behaviour in liquid-solid-supercritical $\mathrm{CO}_{2}$ interfaces. For future applications, it is mandatory that more attempts should be made to optimize the supercritical $\mathrm{CO}_{2}$ process in order to improve protein loading and efficiency through an experimental design.
Proposed mechanism for microparticle formation and lysozyme encapsulation

The mechanism of growth and crystallisation is under debate. Two mechanisms are encountered in the literature to explain the growth and the crystallisation of vaterite hollow microspheres. Some authors ${ }^{58}$ proposed that vaterite microspheres are formed by the self-assembly of nanoparticles (i.e. nanoaggregation). Others ${ }^{59-61}$ proposed that there is first the formation of metastable amorphous calcium carbonate (ACC) microspheres followed simultaneously by their progressive dissolution and a re-precipitation/crystallisation of vaterite around the ACC template. In our study, we observed that lysozyme is trapped in the hollow core of the $\mathrm{CaCO}_{3}$ particles. We can also imagine that first ACC is formed (Fig. 3). The high interaction of the positively charged lysozyme with $\mathrm{CO}_{3}{ }^{2-}$ favours the presence of the protein inside the ACC particles. Then the dissolution of ACC and the rapid precipitation of vaterite around the ACC particles can explain the trapping of lysozyme in the hollow core of the microspheres.

\section{Conclusions}

This work is a starting point of protein encapsulation into $\mathrm{CaCO}_{3}$ microparticles using the supercritical $\mathrm{CO}_{2}$ process as an innovative strategy. Lysozyme, our model protein, has been used to establish the comparison of its encapsulation during $\mathrm{CaCO}_{3}$ growth in supercritical $\mathrm{CO}_{2}$ and in aqueous media. First, $\mathrm{CaCO}_{3}$ microparticles obtained by the supercritical $\mathrm{CO}_{2}$ process were spherical of about $5 \mu \mathrm{m}$ with hollow cores, a rough surface, and composed essentially of vaterite. Using the normal route leads to $\mathrm{CaCO}_{3}$ microparticles of about $3 \mu \mathrm{m}$ with the same polymorph composition. Secondly, when loading lysozyme, there were no changes in morphologies or crystal composition, but only slight differences in sizes. Finally, high encapsulation efficiencies were obtained with the first process $(50 \%)$ with high preserved activity (94\%). The encapsulation yield can be attributed to the low $\mathrm{pH}$ of the aqueous solution, which favours electrostatic interactions between the positively charged lysozyme (IEP $=11.1)$ and calcium carbonate (IEP $=8.5$ ). Furthermore, during the coprecipitation in the $\mathrm{SC}-\mathrm{CO}_{2}$ process, the lysozyme is mainly 
entrapped inside the hollow core of $\mathrm{CaCO}_{3}$ microparticles, which is an advantage for low kinetic release. From a more fundamental point of view, we hypothesized that the precipitation of calcium carbonate may take place through an amorphous $\mathrm{CaCO}_{3} /$ lysozyme precipitation followed by dissolution and crystallisation of vaterite around this metastable polymorph. We also observed an important impact of the lysozyme starting concentration on encapsulation loading and efficiency. Conversely lysozyme was scarcely entrapped in the normal route, probably due to the weak interaction of calcium carbonate and lysozyme at $\mathrm{pH}=10$. Herein we reported a best approach to encapsulate lysozyme and preserve its activity as high as possible. However, this process should be extended to other proteins including growth factors and other bioactive substances.

\section{Acknowledgements}

Particular acknowledgment is made to Rodolphe Perrot and Romain Mallet for confocal and scanning electron microscopy facilities of SCIAM ("Service Commun d'Imagerie et d'Analyse Microscopique”). Emma Donz is also acknowledged for her experimental assistance. We acknowledge the "Région Pays de la Loire "Bioregos 2 project"and the ANR "Agence Nationale pour la Recherche”, grant (ANR-09-PIRI-0004-01 Calcomed) for the financial support.

\section{Notes and references}

1 Y. Yeo, N. Baek and K. Park, Biotechnol. Bioprocess Eng., 2001, 6, 213-230.

2 D. S. Pisal, M. P. Kosloski and S. V. Balu-Iyer, J. Pharm. Sci., 2010, 99, 2557-2575.

3 J. Ho, M. K. Danquah, H. Wang and G. M. Forde, J. Chem. Technol. Biotechnol., 2008, 83, 351-358.

4 M. P. Ginebra, T. Traykova and J. A. Planell, J. Controlled Release, 2006, 113, 102-110.

5 C. Kojima and K. Watanabe, J. Drug Delivery, 2012, 2012, 932461.

6 A. I. Petrov, D. V. Volodkin and G. B. Sukhorukov, Biotechnol. Prog., 2005, 21, 918-925.

7 H. Cölfen, Curr. Opin. Colloid Interface Sci., 2003, 8, 23-31.

8 Y. Zhao, Y. Lu, Y. Hu, J.-P. Li, L. Dong, L.-N. Lin and S.-H. Yu, Small, 2010, 6, 2436-2442.

9 C. Peng, Q. Zhao and C. Gao, Colloids Surf., A, 2010, 353, 132139.

10 T. Ikoma, T. Tonegawa, H. Watanaba, G. Chen, J. Tanaka and Y. Mizushima, J. Nanosci. Nanotechnol., 2007, 7, 822-827.

11 A. Lucas-Girot, M.-C. Verdier, O. Tribut, J.-C. Sangleboeuf, H. Allain and H. Oudadesse, J. Biomed. Mater. Res., Part B, 2005, 73, 164-170.

12 M. Fujiwara, K. Shiokawa, K. Morigaki, Y. Zhu and Y. Nakahara, Chem. Eng. J., 2008, 137, 14-22.

13 D. Zhao, R.-X. Zhuo and S.-X. Cheng, Mol. BioSyst., 2012, 8, 753-759.

14 X. W. He, T. Liu, Y. Xiao, Y. L. Feng, D. J. Cheng, G. Tingting, L. Zhang, Y. Zhang and Y. X. Chen, Cancer Biother.Radiopharm., 2009, 24, 249-259.
15 M.-L. De Temmerman, J. Demeester, F. De Vos and S. C. De Smedt, Biomacromolecules, 2011, 12, 1283-1289.

16 Y. Xiong, A. Steffen, K. Andreas, S. Müller, N. Sternberg, R. Georgieva and H. Bäumler, Biomacromolecules, 2012, 13, 3292-3300.

17 Y. Ueno, H. Futagawa, Y. Takagi, A. Ueno and Y. Mizushima, J. Controlled Release, 2005, 103, 93-98.

18 M. Dierendonck, S. De Koker, C. Cuvelier, J. Grooten, C. Vervaet, J.-P. Remon and B. G. De Geest, Angew. Chem., Int. Ed., 2010, 49, 8620-8624.

19 M. Fujiwara, K. Shiokawa, M. Araki, N. Ashitaka, K. Morigaki, T. Kubota and Y. Nakahara, Cryst. Growth Des., 2010, 10, 4030-4037.

20 A. Lopez-Marzo, J. Pons and A. Merkoci, J. Mater. Chem., 2012, 22, 15326-15335.

21 F. Boury, J. Benoit, O. Thomas and F. Tewes, US Pat., 8367114, 2009.

22 T. Beuvier, B. Calvignac, G. J.-R. Delcroix, M. K. Tran, S. Kodjikian, N. Delorme, J.-F. Bardeau, A. Gibaud and F. Boury, J. Mater. Chem., 2011, 21, 9757-9761.

23 E. A. Chavez Panduro, T. Beuvier, M. Fernandez Martinez, L. Hassani, B. Calvignac, F. Boury and A. Gibaud, J. Appl. Crystallogr., 2012, 45, 881-889.

24 M. K. Tran, L. N. Hassani, B. Calvignac, T. Beuvier, F. Hindré and F. Boury, J. Supercrit. Fluids, 2013, 79, 159-169.

25 M. J. Cocero, Á. Martín, F. Mattea and S. Varona, J. Supercrit. Fluids, 2009, 47, 546-555.

26 M.-K. Tran, A. Swed and F. Boury, Eur. J. Pharm. Biopharm., 2012, 82, 498-507.

27 H. Wakayama, S. R. Hall, Y. Fukushima and S. Mann, Ind. Eng. Chem. Res., 2005, 45, 3332-3334.

28 H. Wakayama, S. R. Hall and S. Mann, J. Mater. Chem., 2005, 15, 1134-1136.

29 W. Gu, D. W. Bousfield and C. P. Tripp, J. Mater. Chem., 2006, 16, 3312-3317.

30 Z. Bing, J. Y. Lee, S. W. Choi and J. H. Kim, Eur. Polym. J., 2007, 43, 4814-4820.

31 C. Shivkumara, P. Singh, A. Gupta and M. S. Hegde, Mater. Res. Bull., 2006, 41, 1455-1460.

32 J. M. Bezemer, R. Radersma, D. W. Grijpma, P. J. Dijkstra, C. A. van Blitterswijk and J. Feijen, J. Controlled Release, 2000, 67, 233-248.

33 B. Kerkaert, F. Mestdagh and B. De Meulenaer, Food Chem., 2010, 120, 580-584.

34 I. M. A. Verhamme, G. W. K. Van Dedem and A. R. Lauwers, Eur. J. Biochem., 1988, 172, 615-620.

35 D. V. Volodkin, A. I. Petrov, M. Prevot and G. B. Sukhorukov, Langmuir, 2004, 20, 3398-3406.

36 G. B. Sukhorukov, D. V. Volodkin, A. M. Gunther, A. I. Petrov, D. B. Shenoy and H. Mohwald, J. Mater. Chem., 2004, 14, 2073-2081.

37 A. E. Voinescu, D. Touraud, A. Lecker, A. Pfitzner, W. Kunz and B. W. Ninham, Langmuir, 2007, 23, 12269-12274.

38 X. Wang, H. Sun, Y. Xia, C. Chen, H. Xu, H. Shan and J. R. Lu, J. Colloid Interface Sci., 2009, 332, 96-103.

39 D. V. Volodkin, N. I. Larionova and G. B. Sukhorukov, Biomacromolecules, 2004, 5, 1962-1972. 
40 M. B. Brown and S. A. Jones, J. Eur. Acad. Dermatol. Venereol., 2005, 19, 308-318.

41 C. Domingo, E. Loste, J. Gómez-Morales, J. García-Carmona and J. Fraile, J. Supercrit. Fluids, 2006, 36, 202-215.

42 F. C. Meldrum and H. Colfen, Chem. Rev., 2008, 108, 4332-4432. 43 A.-J. Xie, Y.-H. Shen, C.-Y. Zhang, Z.-W. Yuan, X.-M. Zhu and Y.-M. Yang, J. Cryst. Growth, 2005, 285, 436-443.

44 F. Manoli, J. Kanakis, P. Malkaj and E. Dalas, J. Cryst. Growth, 2002, 236, 363-370.

45 S. R. Dickinson and K. M. McGrath, Cryst. Growth Des., 2004, 4, 1411-1418.

46 X. Ma, H. Yang, H. Chen, L. Yang, Y. Guo and Y. Si, J. Cryst. Growth, 2011, 327, 146-153.

47 H. Yang, W. Yao, L. Yang, X. Ma, H. Wang, F. Ye and K. Wong, J. Cryst. Growth, 2009, 311, 2682-2688.

48 J. Kanakis and E. Dalas, J. Cryst. Growth, 2000, 219, 277-282.

49 Y. Liu, Y. Cui, H. Mao and R. Guo, Cryst. Growth Des., 2012, 12, 4720-4726.

50 J. Zhan, H. P. Lin and C. Y. Mou, Adv. Mater., 2003, 15, 621623.

51 A. Gutjahr, H. Dabringhaus and R. Lacmann, J. Cryst. Growth, 1996, 158, 296-309.
52 M. Sedlák and H. Cölfen, Macromol. Chem. Phys., 2001, 202, 587-597.

53 N. Koga, Y. Nakagoe and H. Tanaka, Thermochim. Acta, 1998, 318, 239-244.

54 R. M. Pytkowicz and D. N. Conners, Science, 1964, 144, 840841.

55 Y. Ueno, H. Futagawa, Y. Takagi, A. Ueno and Y. Mizushima, J. Controlled Release, 2005, 103, 93-98.

56 A. Bouchard, N. Jovanović, W. Jiskoot, E. Mendes, G.-J. Witkamp, D. J. A. Crommelin and G. W. Hofland, J. Supercrit. Fluids, 2007, 40, 293-307.

57 M. A. Winters, B. L. Knutson, P. G. Debenedetti, H. G. Sparks, T. M. Przybycien, C. L. Stevenson and S. J. Prestrelski, J. Pharm. Sci., 1996, 85, 586-594.

58 W. Wei, G.-H. Ma, G. Hu, D. Yu, T. McLeish, Z.-G. Su and Z.-Y. Shen, J. Am. Chem. Soc., 2008, 130, 15808-15810.

59 J. G. Yu, H. Guo, S. A. Davis and S. Mann, Adv. Funct. Mater., 2006, 16, 2035-2041.

60 J. Yu, H. Yu, H. Guo, M. Li and S. Mann, Small, 2008, 4, 87-91.

61 J. Tark Han, X. Xu and K. Cho, J. Cryst. Growth, 2007, 308, 110-116. 